DOI 10.18551/rjoas.2019-10.19

\title{
THE ANALYSIS OF SOCIAL AND GENETIC RELATIONSHIP CHANGES AMONG BURU COMMUNITY FROM CONTEMPORARY PERSPECTIVE
}

\author{
Lopulalan Dortje L.Y.* \\ Postgraduate Program of Sociology Study, Makassar State University, Indonesia \\ Sahabudin Jumadi, Syukur Muhammad \\ Postgraduate Program of Social Science Study, Makassar State University, Indonesia \\ *E-mail: nor lopulalan@yahoo.co.id
}

\begin{abstract}
Social change in the community certainly has more or less an impact on the kinship conditions of a group in certain places along the changing times. This qualitative study analyzed the social change and kinship conditions of the Buru people in a contemporary perspective on the Buru island of Maluku Province. To understand these changes, a series of data collection was carried out through observation, in-depth interviews and or focused group discussion (FGD). The results found that kinship in the Buru community can be seen from the kinship of family lineages, the kinship of the origin of history and marital kinship. Changes in the value system as a culture in Buru society can be seen with the emergence of changes in lifestyle, attitudes-individualistic and materialistic society. In the Buru community, solidarity helps others begin to fade. This can be seen with the beginning to fade a sense of caring, meet each other greet and the loss of togetherness between families. The loss of a sense of togetherness according to the findings of this study was due to the development of communication facilities so that face-to-face meetings are no longer considered important. On the other hand, the need for promotional information encourages people to use communication technology tools such as mobile phones. Kinship in the process of housing construction called "ngepu ngeso" also began to fade and was replaced by a commercialization system. The entry of modernization in the midst of society resulted in the disappearance of kinship and togetherness such as mutual cooperation culture and other social relations.
\end{abstract}

\section{KEY WORDS}

Social change, Buru People genetic kinship, contemporary perspective.

Outermost islands bordering on neighboring countries of Indonesia (Presidential Decree No. 6 of 2017). The island of Buru is classified as a small island and the community is classified as indigenous people who tend to be homogeneous. Various studies prove that culture in society can fade due to various social changes. Each region will naturally experience changes as interactions occur, both interactions that occur internally and externally. Change can occur because of human awareness in locality and changes that occur due to transformations originating from outside. One island that has changed physically and non-physically is the island of the Buru. Buru Island is a new autonomous region that was once part of the Central Maluku Regency which has now become two new districts namely Buru and South Buru. The Cultural element is still very much attached to the lives of the people of Pulau Buru.

Cultural elements are still visible from a series of symbols that express beliefs, rituals, art, identity, and behavior of the community. Culture is often a part that changes in Buru Island society. In addition, the entry of technology and rapid development has led to changes in culture and social structure in the community of Buru Island. Buru island communities also experience a transition or change in the form of social differentiation both vertically and horizontally. This situation also affects aspects of people's lives, especially socioeconomic life experiencing changes both decrease and increase. 
Geographically the existence of communities on the island of Buru is concentrated in the mountains and the coast. The people who live in the mountains are indigenous people who mostly control the land. While those who live on the coast are people who are mostly settled settlers and mostly traders. Social change in society is a social phenomenon, whether the change is planned or not. Each component that affects change must be related to one another, various things can cause a social change, one of which is development. Many factors influence social change in trans-migrant communities. Soekanto (1982), argues that the factors that cause social change are sourced from within the community namely: increasing or decreasing population, new discoveries, conflicting conflicts within the community both individuals and groups, the occurrence of rebellions or revolutions in society. The factors originating from outside the community, namely: causes originating from the physical environment that is around humans, warfare, and cultural influences of other communities. This study aimed to look at social change and the kinship conditions of people in Buru in a contemporary perspective".

Changes in society are in principle a continuous process which means that each community will, in fact, experience changes, but changes between groups and other groups are not always the same (complex) and many factors influence it (Hatu, 2011). Vago (2004) defines social change as a planned or unplanned process, qualitative or quantitative, changes in social phenomena, which can be categorized into six interrelated components called identity, level, duration, direction, scale (magnitude) and speed of change. In line with the opinion of Hatu, Ogburn (1964) argues that social change includes technological changes that result in changes in the material environment and regulate it, thereby causing changes or modifications in social habits and institutions. cultural value of a village. Cultural change refers to changing patterns of behavior, including technology and dimensions of science, material and non-material (Hatu, 2011).

Identity change refers to specific social phenomena that are undergoing changes such as certain habits, behaviors, attitudes, patterns of interaction, authority structures, levels of productivity, patterns of voting, self-esteem and stratification systems. Society as an important part of a country, formed in a social system with all the cultures and customs that they have. Changes that occur in the environment will greatly affect people's lives. Society is the main subject that will be affected by the change. How these changes affect the community depends also on how the community can respond to existing changes. Changes as a whole will give certain reactions from the community according to how sensitive its influence on people's lives.

Harper (1989) argues that social change is a significant change in social structure based on time. Every society during its life must undergo change. Changes for the community concerned as well as for outsiders who examine them can be in the form of changes that are not interesting in the sense of less striking. There are also changes whose influence is limited or broad, and there are also chances that are very slow, but some are running fast. According to Soekanto (2009), social change is any change in social institutions within a society, which affects its social system, including values, attitudes, and patterns of behavior among community groups. Changing a system, from a particular system to another different system will take time and will change gradually.

As explained earlier that change will always happen, in other words, change is something dynamic and will continue to change. This change is a social process, Sztompka (2007) divides this type of social process into a typology based on four criteria; 1 ) the form of social processes that occur; 2) the results; 3) awareness of social processes among members of the community concerned; 4) the power that drives the process. This means that conditions in the community will affect the social process. Referring to the phrase Stzompka (2007) which states that changes that occur in the community will have good or bad effects depending on how the community responds Sztompka (2007) which states that social change can be imagined as a change that occurs in or including social systems, more precisely, there are differences between the state of certain systems in different time periods.

Basrowi (2005) discusses cultural lag as a form of cultural change. In addition to cultural lag, there are other cultural events that occur due to changes, namely cultural 
survival, cultural conflict, and cultural shock. Cultural survival is defined as the existence of a traditional method that has not been changed since then until now. Cultural conflict or cultural conflict is a process of conflict between one culture and another culture. Cultural shock or cultural shock is a process of cultural transfer that suddenly causes a shock to the recipient of the change. These events will accompany the community when social changes occur in the community system. Harper (1989) argues that social change is a significant change in social structure based on time. Blau's (1998) explains that there are two types of structural parameters namely nominal parameters and gradual parameters. Nominal parameters distinguish members of the population with discrete categories, such as gender, ethnicity, and religion. The gradual parameters differentiate members based on levels, such as income, age, wealth, power, socio-economic status, and prestige.

\section{METHODS OF RESEARCH}

This research used a constructionist paradigm. This paradigm viewed social science as a systematic analysis of the meaning of social action through direct observation (Dedy Mulyana, 2003). The constructionist paradigm is considered to have the ability to solve as an imperfect problem by making a more natural setting, gathering more site information. This research used the descriptive qualitative method. Data collection was done by observation, in-depth interviews and or focused group discussions (FGD). The location of the research was Maluku Buru Island. Ambon Province. The location selection was done intentionally. Data collected included primary data and secondary data. Primary data obtained from observation, in-depth interviews and focus group discussions discussion (FGD). Secondary data were obtained from the Village Office and previous research reports. The selection of informants was carried out in a purposive sampling technique. Data analysis techniques are performed data collection, data analysis, data reduction, data presentation, and drawing conclusions (Denzin, 2009).

\section{RESULTS AND DISCUSSION}

Socio-economic characteristics of the community. Sociologically, the people of Buru have a culture that is almost the same as that of other regions. Buru Island experienced five periods of influence and changes in occupation, namely the period of the Sultan of Ternate, Portuguese, Dutch, Japanese and Indonesian. In the period of the Sultan of Ternate, besides trade, there was also the mobilization of residents from Sula and Sanana to plant coconut trees. The eucalyptus and resin trade is carried out through the most profitable trade relations with Sultan Buton and Sultan Bone. Then the Portuguese made trade instability between the Sultan of Ternate with Arab and Chinese traders on the Kayeli plain (Pattinama, 2013). Along with the independence of Indonesia and the establishment of the Republic of Indonesia in 1945. The Buru region has an area of $12,345 \mathrm{Km} 2$ consisting of one large island, the Buru Island and various small islands, namely Ambalau Island, White Sand Island, Fogi Island, Tomahu Island, and Oki Island. Originally the region had only two districts, Namely the North Buru District with the capital of Namlea and South Buru District with the capital of Leksula.

There are several ethnic groups living in Buru: indigenous, namely Buru (both on the coast and in the interior) and ethnic migrants, namely Ambon, Southeast Maluku (mainly Kei), Ambalau, Kep. Sula (especially Sanana), Buton, Bugis, and Java (especially in transmigration settlement areas). Buru Regency (Buru in 2012 figures) when it was formed consisted of three districts namely North Buru, North Buru, and West North Buru. But traditionally, in the Buru Regency region itself, it is also divided into 8 petuanan areas namely Kayeli, Liliali, Tagalisa, Lisela, Masarete, Fogi, Waisama, and Ambalau, each petuanan is led by a king. Kayeli is a village in the Kaiely Bay District, Buru Regency, Maluku Province. Kaiely is two syllables namely Kai and Ely. "Kai" which means sister, "Ely" which means beach. The Kayeli people mostly work as fishermen and gardeners. Long-term plantation crops such as coconuts, cocoa, and cloves and similar crops. The Kayeli community is 
currently faced with social change due to the arrival of migrants. The arrival of migrants has affected the lives of local people on the island of Buru. In the social aspect of kinship, the Kayeli community builds a loving relationship among the community through the provision of food, goods, hamlet and even land to relatives in need.

Kinship relations in society are woven into three bonds. First, kinship through genealogy. kinship through genealogy is a kinship formed through family lineage and family kinship. Both kinship origins. relatives of origin are those who live somewhere and then spread and domicile in a new place and determine the origin through historical events. All three are related by marriage. kinship due to marriage formed because a native Buru man or woman marries a non-Buru person, his children as well as parents and siblings of his wife or non-Buru husband are also included in the Kay-Wait relationship as Buru's siblings. The social change of the Buru island region does not affect the values of the customs of the hunting community, such as the custom of wedding celebrations, childbirths, and religious holidays.

Understanding of Buru People in Contemporary Perspectives. Cultural change refers to changing patterns of behavior, including technology and dimensions of science, material and nonmaterial (Hatu 2011). Cultural changes that will be discussed in this study include changes in the value of customs, technology, changes in materialistic ways, and changes in togetherness. In the history of the development of society, there are always two changes, namely changes that occur in a revolutionary and also evolutionary manner. Revolution is characterized more quickly, deconstructively, and has a much greater potential for conflict than evolution where it is slower, constructive, and minimally conflicted. Likewise what happened to the people in Buru Regency, with the progress achieved not a little later led to changes.

In an effort to develop an area has the potential to change the way people behave and lifestyle in the region. Changes in the value system as a culture in society are evident with the emergence of individualistic and materialistic attitudes of society. The threat of westernization is always open, as easy access to transformation and information in Buru Regency. It is important to remember that the inhabitants of the island of Buru are not only indigenous people who depart from traditions that are considered sacred, the arrival of transmigrants, the exodus of Ambonese inhabitants, as well as the arrival of miners also have negative implications for the traditional values of the Buru people themselves. One potential lifestyle change that is individualistic.

Table 1 - The Dialectics of Kaywait Values in Contemporary Perspectives

\begin{tabular}{|c|c|c|}
\hline Moment & Process & Phenomena \\
\hline Externalisation & $\begin{array}{l}\text { Self adaptation to the } \\
\text { sociology-cultural } \\
\text { world }\end{array}$ & $\begin{array}{l}\text { Kaywait values belong to the Kayeli community, to the people whose } \\
\text { kinship relationships are still maintained }\end{array}$ \\
\hline Objectiveness & $\begin{array}{l}\text { Self interaction with } \\
\text { the socio-cultural } \\
\text { world }\end{array}$ & $\begin{array}{l}\text { kaywait value manifested in social interactions between individuals } \\
\text { which is manifested in daily activities and behaviors such as living } \\
\text { standard of love which is reflected through the provision of food, goods, } \\
\text { hamlet and even land. } \\
\text { Sense of togetherness began to decrease and the distance } \\
\text { Means of communication } \\
\text { The fading of kinship in relatives in development activities began. }\end{array}$ \\
\hline Internalisation & $\begin{array}{l}\text { Self-identification } \\
\text { with the socio- } \\
\text { cultural world }\end{array}$ & $\begin{array}{l}\text { Families / individual cultural actors who are dominated by thinking agree } \\
\text { on the importance of the Kaywait values in building a harmonious } \\
\text { shared life. }\end{array}$ \\
\hline
\end{tabular}

Individualist is someone who considers himself more important than others. A person's individualist attitude is characterized by a lack of communication and interaction between one individual and another and a lack of concern for the interests of others around him. In the community, the hunt for solidarity helps others begin to fade. This can be seen with the beginning to fade a sense of caring, meet each other greet and the loss of togetherness between families. The loss of a sense of togetherness is allegedly due to the development of communication facilities so that face-to-face meetings are no longer considered important. on 
the other hand, information needs promotion encourages people to use android-based mobile phones. Mobile phones help people get unlimited information and promotions to a wide audience with the help of the internet. Kinship in the process of housing construction called "ngepu ngeso" also faded and was replaced by commercialization. The entry of modernization in the midst of society eliminates mutual cooperation culture. Indications of uneven changes in all levels of society also lead to lagging changes.

This reality continues to grow in line with the development of community life. This process will continuously give birth to something new. There will be a halt phase before then progressing to the next phase. Social reality always develops from phase to phase and will stop (objectified). In each phase there is a change in the new value that replaces the old value. The process of the metamorphosis of kaywait is a form of self-expression effort carried out by the Kayeli community into the cultural arena, in the form of mental and physical activities. This process is self-expression to strengthen the existence of individuals in society.

\section{CONCLUSION}

Kinship in the community of the people of the Buru can be seen from the kinship of the family lineage, the kinship of the historical origins and the marriage relationship. Changes in the value system as a culture in the society of people are seen with the emergence of changes in lifestyle, attitudes, individualistic and materialistic society. In the community, the Buru for solidarity helps others begin to fade. This can be seen with the beginning to fade a sense of caring, meet each other greet and the loss of togetherness between families. The loss of a sense of togetherness was allegedly due to the development of communication facilities so that face-to-face meetings were no longer considered important. On the other hand, the need for promotional information encourages people to use mobile phones. Kinship in the process of housing construction called "ngepu ngeso" also faded and was replaced by a system of commercialization. The inclusion of modernization in the midst of the community eliminates mutual cooperation culture.

\section{REFERENCES}

1. Basrowi. 2005. Pengantar Sosiologi. Bogor. Ghalia Indonesia.

2. Berger, Peter L., Luckmann, Thomas. 1966. The Social Construction of Reality, The Treatise In The Sociology of Reality. Garden City, N.Y.: Doubleday.

3. Berger Peter L and Luckmann T. 1990. Tafsir Sosial Atas Kenyataan. Risalah tentang Sosiologi Pengetahuan.

4. Blau PM. 1977. A Macrosociological Theory of Social Structure. The American Journal of Sociology. Vol. 83, No. 1 (Jul. 1977) 26-54.

5. Dedy Mulyana, 2003. Metodologi Penelitian Kualitatif. Bandung, PT Remaja Rosdakarya.

6. Denzin, Norman K. and Lincoln, Yvonna S, 2009, Handbook of Qualitative Research, diterjemahkan oleh Dariyatno dkk, Pustaka Pelajar, Yogyakarta.

7. Herper CL. 1989. Exploring Social Change. New Jersey, Prentice-Hall, Inc.

8. Hatu R. 2011. Perubahan Sosial KulturalMasyarakat Pedesaan: Suatu Tinjauan TeoritikEmpirik. Jurnal Inovasi . Vol 8 (4): 1-11.

9. Ogburn WF. 1964. Culture and Social Change. Chicago: University of Chicago Press.

10. Pattinama, Prof. Dr. Ir. Max Marcus J. D.E.A .2013. Cerita Tentang Tempat Keramat Di Dataran Rana, Pulau Buru, Maluku.

11. Ritzer, George. 2004. Teori Sosial Postmodern. Yogyakarta. Kreasi Wacana.

12. Soekanto. 2009, Sosiologi Suatu Pengantar, Edisi Baru: Rajawali Pers.Jakarta.

13. Syapsan, Basri S, llyas E. 2010. Perubahan Sosial Masyarakat Pasca Pembangunan PembangkitListrik Tenaga Air (PLTA) Koto Panjang Provinsi Riau.Jurnal Ekonomi Vol 18 (2):17-22.

14. Sztompka, P. 2007. Sosiologi Perubahan Sosial. Jakarta (ID): Prenada Media Group.

15. Vago S. 2004. Social change. London: Pearson Pentice-Hall. 